\title{
PROFIL PEMAHAMAN KONSEP TEOREMA PYTHAGORAS SISWA BERDASARKAN PERBEDAAN GAYA KOGNITIF FIELD INDEPENDENT DAN FIELD DEPENDENT
}

\author{
Nurafni $^{1}$, Asih Miatun ${ }^{2}$, Hikmatul Khusna ${ }^{3}$ \\ ${ }^{1}$ Universitas Muhammadiyah Prof. DR. HAMKA \\ nurafni@uhamka.ac.id \\ ${ }^{2}$ Universitas Muhammadiyah Prof. DR. HAMKA \\ asihmiatun@uhamka.ac.id \\ ${ }^{3}$ Universitas Muhammadiyah Prof. DR. HAMKA \\ hikmatulhusna@uhamka.ac.id
}

\begin{abstract}
ABSTRAK
Penelitian ini adalah penelitian deskriptif dengan pendekatan kualitatif yang bertujuan untuk mendeskripsikan profil pemahaman konsep teorema Pythagoras siswa berdasarkan perbedaan gaya kognitif field independent dan field dependent. Subjek penelitian adalah siswa kelas 9 SMP. Penentuan subjek dilakukan dengan menggunakan instrumen GEFT dan hasil konsultasi dengan guru matematika, dilanjutkan dengan pemberian tes pemahaman konsep pada materi teorema pythagoras dan wawancara. Pengecekan keabsahan data dilakukan dengan triangulasi waktu. Hasil penelitian menunjukan bahwa pemahaman siswa dengan gaya kognitif field dependent terhadap teorema pythagoras yaitu 1) Siswa menyatakan makna teorema Pythagoras yang diberikan menggunakan bahasanya sendiri dengan menyebutkan definisi teorema Pythagoras yang diketahui; 2) Siswa ketika penggunaan konsep teorema Pythagoras, siswa menggunakan gambar segitiga sebagai representasi untuk mempermudah menafsirkan letak sisi-sisi yang diberikan. Siswa mencari nilai yang belum diketahui dan menggunakan teorema Pythagoras untuk menyelesaikan masalah; 3) Siswa menggunakan syarat perlu atau syarat cukup suatu konsep untuk menentukan luas segitiga menggunakan teorema Pythagoras dengan cara terlebih dahulu mencari sisinya. Sedangkan hasil penelitian pemahaman siswa dengan gaya kognitif field independent terhadap teorema pythagoras yaitu 1) Siswa menyatakan makna teorema Pythagoras dengan menggunakan bahasanya sendiri dengan menyebutkan simbol-simbol yang diketahui pada teorema Pythagoras; 2) Siswa menggunakan konsep teorema Pythagoras untuk menyelesaikan masalah yang diberikan dengan cara menggunakan operasi hitung perkalian untuk menentukan salah satu sisi yang belum diketahui. Siswa menggunakan teorema Pythagoras untuk menemukan jawaban dari soal yang diberikan; 3) Siswa menggunakan syarat perlu atau syarat cukup suatu konsep teorema Pythagoras dengan menyatakan bahwa harus diketahui dua sisi atau tidak cukup jika diketahui satu sisi saja.
\end{abstract}

Kata Kunci: Pemahaman Konsep, Field Independent, Field Dependent, Teorema Pythagoras

\begin{abstract}
This research is a descriptive qualitative approach which aims to describe profile of understanding of pythagoras theorem concept of students based on the difference of field independent
\end{abstract}


and dependent cognitive style. The subjects of this study are 9th grade students of junior secondary school. Subject determination is done using GEFT instrument and mathematics teacher's consultation, then continued by giving concept comprehension test on Pythagorean theorem material and interview. Checking the validity of data is done by time's triangulation. The results showed that student: 1) states the meaning of Pythagoras's theorem given in his own language by noting Pythagorean theorem's definition; 2) when using the concepts of Pythagoras theorem, students use triangle images as representations to facilitate an interpretation of given sides position. Then the students find the unknown values and use Pythagoras theorem to solve the problem; 3) using the necessary condition or sufficient condition of a concept to determine the area of a triangle using Pythagorean theorem by finding a side. While, the results for field independent cognitive style are student: 1) expresses the meaning of Pythagoras theorem by using their own language and mentioning the symbols; 2) using the concepts of Pythagorean theorem to solve the problem given by using multiplication operations to determine one of unknown sides. Then, student use pythagoras theorem to find the answer of the given problem; 3) using the necessary conditions or sufficient terms a concept of Pythagoras theorem by stating that it must be known two sides or not.

Keywords: Conceptual Understanding, Field Independent, Field Dependent, Pythagoras Theorem

Format Sitasi: Nurafni, Miatun, A., \& Khusna, H. (2018). Profil Pemahaman Konsep Teorema Pitagoras Siswa Berdasarkan Perbedaan Gaya Kognitif Field Independent dan Field Dependent. KALAMATIKA Jurnal Pendidikan Matematika, 3(2), 175-192.

Penyerahan Naskah: 2 Februari 2018 || Revisi: 11 Agusutus 2018 || Diterima: 11 Agustus 2018

\section{PENDAHULUAN}

Teorema Pythagoras merupakan materi yang familiar pada pelajaran matematika. Teorema pythagoras ini telah diperkenalkan di sekolah dasar dalam bentuk yang sederhana. Pemahaman siswa dalam konsep teorema pythagoras merupakan hal yang penting. Ketika siswa telah memiliki pemahaman konsep teorema pythagoras, maka siswa dapat mengaitkan serta mengembangkan konsep tersebut untuk menyelesaikan masalah matematika. Namun apabila pemahaman konsep siswa dalam teorema pythagoras rendah, maka siswa akan kesulitan dalam menyelesaikan masalah matematika yang berkaitan dengan teorema pythagoras. Menilik penyataan di atas, maka perlu diketahui pengertian dari pemahaman itu sendiri. Menurut Hamalik (2009) pemahaman adalah kemampuan melihat hubunganhubungan antara berbagai faktor atau unsur dalam situasi yang problematis. Sedangkan Dimyati \& Mujiono (2009) memberikan pengertian bahwa pemahaman (comprehension) berisikan kemampuan untuk memaknai dengan tepat apa yang telah dipelajari tanpa harus menerapkannya. 
Pemahaman konsep adalah pengetahuan secara menyeluruh terhadap konsep dasar matematika beserta dasar dibalik algoritma tersebut. Pemahaman konsep merupakan situasi dimana siswa menemukan dan membuktikan sendiri suatu konsep tanpa proses hafalan. Ghazali \& Zakaria (2011) menjelaskan bahwa pemahaman konsep memungkinkan siswa untuk memecahkan masalah matematika dalam berbagai bentuk dan aturan baru. Siswa dengan pengetahuan konseptual tingkat tinggi mampu memecahkan masalah yang belum pernah mereka alami sebelumnya.

Masalah yang terjadi di lapangan, seperti yang dikemukakan oleh Ikrima (2015) bahwa siswa merasa bingung menerapkan konsep teorema pythagoras ketika menghadapi suatu soal dan ketika dihadapkan pada suatu soal yang sudah mereka mengerti, apabila soalnya diganti siswa kembali bingung untuk mengerjakannya. Dari kasus tersebut, maka kemampuan pemahaman matematis harus disoroti agar siswa memiliki pemahaman konsep teorema pythagoras yang mendalam. Oleh karena itu, diperlukan reformasi dalam pengajaran untuk meningkatkan pemahaman konseptual di kalangan siswa guna meminimalkan penggunaan rumus yang ada dan menghafal rumus.

Darminto (2009) mengungkap bahwa indikator pemahaman konsep sebagai berikut: 1) menyatakan atau menjelaskan ulang sebuah konsep; 2) mengklasifikasikan sifat-sifat tertentu, 3) memberi contoh; 4) merepresentasikan konsep; 5) menggunakan konsep untuk menyelesaikan masalah. Menurut NCTM (1989) untuk mengetahui pemahaman siswa terhadap konsep matematika dapat dilihat dari kemampuan siswa dalam: 1) mendefinisikan konsep secara verbal dan tulisan; 2) mengidentifikasi dan membuat contoh dan bukan contoh; 3) menggunakan model, diagram, dan simbol-simbol untuk merepresentasikan suatu konsep; 4) mengubah suatu bentuk representasi kebentuk lainnya; 5) mengenal berbagai makna dan interpretasi konsep; 6) mengidentifikasi konsep-konsep dan mengenal syarat yang menentukan suatu konsep; 7) membandingkan dan membedakan konsep-konsep.

Siswa yang memiliki pemahaman konsep yang baik akan berpengaruh pada perkembangan kognitifnya. Cools (2009) menyebutkan bahwa "one of the factors studied in the contex are cognitive style, which have been defined as the way people perceive stimuli and how they use this informatian to guide their behavior". Oleh karena itu guru juga harus memperhatikan gaya kognitif yang dimiliki siswa. Hal ini sejalan dengan pendapat Minggi (2010) bahwa memperhatikan gaya kognitif siswa sangat diperlukan dalam proses 
pembelajaran, agar materi yang dipelajari dapat dipahami dengan baik dan pengetahuan dapat tersimpan dalam memori jangka panjang secara baik.

Ausburn (Uno, 2006) merumuskan bahwa gaya kognitif mengacu pada proses kognitif seseorang yang berhubungan dengan pengetahuan, pemahaman, pengetahuan, persepsi, pikiran, imajinasi dan pemecahan masalah. Riding (1997) mengelompokkan gaya kognitive menjadi beberapa kelompok antara lain: 1) field-dependency-independency; 2) levellingsharpening; 3) impulsivity-reflectiveness; 4) converging-diverging thinking; 5) holist-serialis tingking; 6) asimilator explores; 7) adaptors-innovators; 8) reasoning-intuituve activecontemlative; 9) abstrack-concrete thinker dan 10) verbaliser-visualiser. Dalam penelitian ini menggunakan gaya kognitif field-dependency-independency karena pengolahan informasi pada gaya kognitif berdasar pada bergantung atau tidaknya dengan faktor lingkungan. Tinjauan ini berdasakan perbedaan tiap-tiap individu pada ketergantungan terhadap lingkungan ketika melakukan proses analisis, berpikir dan belajar.

Definisi untuk individu dengan gaya kognitif field dependent (FD) dan individu dengan gaya kognitif field independent (FI) dijelaskan sebagai berikut.

\section{Gaya Kognitif Field Dependent}

Ciri-ciri individu field dependent (FD) dalam belajar menurut Liu \& Ginter (1999), yaitu 1) menerima konsep dan materi secara umum; 2) agak sulit menghubungkan konsepkonsep dalam kurikulum dengan pengalaman sendiri atau pengetahuan awal yang telah mereka miliki; 3) suka mencari bimbingan dan petunjuk guru; 4) memerlukan hadiah atau penghargaan untuk memperkuat interaksi dengan guru; 5) suka bekerjasama dengan orang lain dan menghargai pendapat serta perasaan orang lain; 6) lebih suka bekerjasama daripada bekerja sendiri; 7) lebih menyukai organisasi materi yang disiapkan oleh guru.

Siswa dengan gaya kognitif field dependent lebih menggunakan pendekatan pasif dalam belajar. Tujuan pembelajaran cenderung diikuti apa adanya, sehingga diperlukan tujuan pembelajaran yang tersusun dengan baik. Dalam pembelajaran individu field dependent menginginkan materi pembelajaran yang tersusun dengan baik dan dinyatakan secara eksternal, motivasi eksternal, penguatan eksternal, dan petunjuk guru.

\section{Gaya Kognitif Field Independent}

Menurut Liu \& Ginter (1999) ciri-ciri individu Field Independent (FI) dalam belajar, yaitu: 1) memfokuskan diri pada materi kurikulum secara rinci; 2) memfokuskan diri pada 
fakta dan prinsip; (3) jarang melakukan interaksi dengan guru; (4) interaksi formal dengan guru hanya dilakukan untuk mengerjakan tugas, dan cenderung memilih penghargaan secara individu; (5) lebih suka bekerja sendiri; (6) lebih suka berkompetisi; dan (7) mampu mengorganisasikan informasi secara mandiri.

Berdasarkan latar belakang yang telah dikemukakan, peneliti tertarik untuk mengetahui bagaimana pemahaman siswa dengan gaya kognitif filed independent dan filed dependent pada konsep teorema pythagoras.

\section{METODE PENELITIAN}

Penelitian ini adalah penelitian kualitatif dimana pada penelitian kualitatif lebih menekankan proses daripada hasil. Tujuan penelitian ini untuk mendeskripsikan profil pemahaman siswa terhadap konsep teorema pythagoras ditinjau dari perbedaan gaya kognitif FI dan FD.

Pemilihan subjek dilakukan berdasarkan tes kemampuan yang diberikan. Tes kemampuan pertama yang diberikan adalah tes kemampuan gaya kognitif dengan menggunakan instrumen Group Embedded Figures Test (GEFT). Pengelompokan siswa ke dalam satu tipe gaya kognitif field independent dan field dependent didasarkan atas kemampuan yang dimiliki siswa dalam menyelesaikan tes GEFT.

Pengkategorian atau penggolongan siswa field independent dan siswa field dependent beserta skornya disajikan dalam Tabel 1.

Tabel 1. Kategori Gaya Kognitif

\begin{tabular}{cc}
\hline Skor & Kategori Gaya Kognitif \\
\hline $0 \% \leq$ Gaya Kognitif $\leq 50 \%$ & Field Dependent (FD) \\
$50 \%<$ Gaya Kognitif $\leq 100 \%$ & Field Independent (FI) \\
\hline
\end{tabular}

Adapun analisis yang dilakukan dalam penelitian ini dengan menggunakan prosedur Miles \& Huberman (Sugiyono, 2012) yaitu: Mereduksi data, Pemaparan data dan menarik kesimpulan.

\section{HASIL DAN PEMBAHASAN}

Pada penelitian ini, data diambil dari Tes Pemahaman Konsep Teorema Pythagoras (TPKTP) pada setiap subjek yang kemudian dilakukan wawancara berdasarkan hasil pekerjaan subjek masing-masing, dimana subjek tersebut mewakili gaya kognitif field dependent dan field independent. Hasil penelitian yang telah direduksi disajikan sebagai berikut: 


\section{Menyatakan Teorema Pythagoras Menggunakan Bahasanya Sendiri}

Hasil tertulis subjek field independent (S1) ketika menyatakan makna teorema Pythagoras yang diberikan menggunakan bahasanya sendiri dalam TPKTP I untuk nomor 1 dan 3, pada Gambar 1 dan Gambar 2:

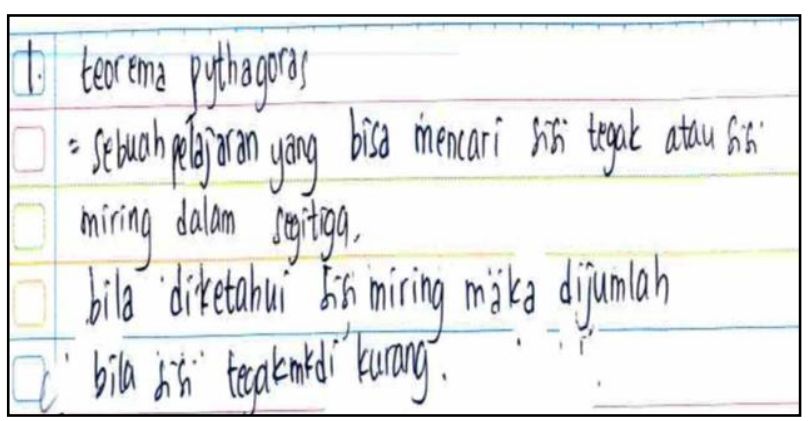

Gambar 1. Jawaban Subjek S1.1.1

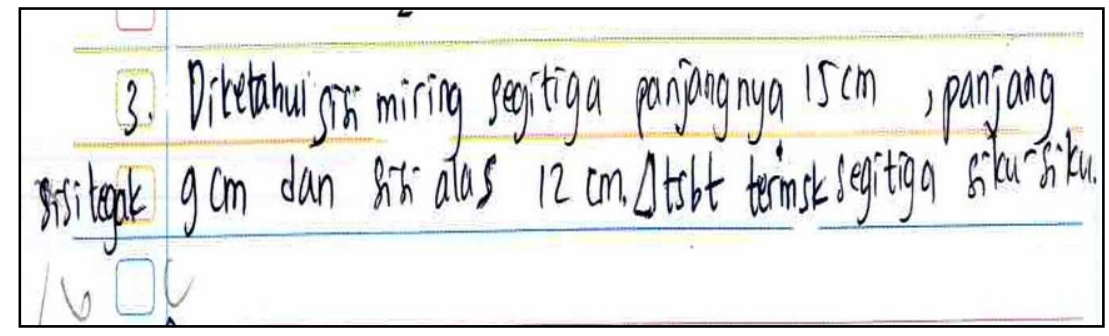

Gambar 2. Jawaban Subjek S1.1.3

Cuplikan wawancara subjek S1 ketika menyatakan makna teorema Pythagoras yang diberikan menggunakan bahasanya sendiri dalam TPKTP I untuk nomor 1.

P1,1,2 : apa yg anda ketahui mengenai teorema pythagoras?

S1,1,2 : sebuah pelajaran yang bisa mencari sisi tegak atau sisi miring dalam segitiga. Bila diketahui sisi miring maka dijumlah, bila sisi tegak maka dikurang.

Cuplikan wawancara subjek S1 ketika menyatakan makna teorema Pythagoras yang diberikan menggunakan bahasanya sendiri dalam TPKTP I untuk nomor 3

P1,1,30 : coba apa yang bisa kamu simpulkan (dari soal no.3)?

S1,1,30 : diketahui sisi miring segitiga panjangnya $15 \mathrm{~cm}$, panjang sisi tegak $9 \mathrm{~cm}$ dan sisi alas $12 \mathrm{~cm}$. segitiga tersebut termasuk segitiga siku-siku

Penjelasan data subjek S1 dalam pengerjaan TPKTP I dan TPKTP II disajikan pada Tabel 2 berikut. 
Tabel 2. Paparan Data Pemahaman Subjek S1 ketika Menyatakan Makna Teorema Pythagoras yang Diberikan pada TPKTP I dan TPKTP II

\begin{tabular}{ll}
\hline Data TPKTP I & \multicolumn{1}{c}{ Data TPKTP II } \\
\hline $\begin{array}{l}\text { Subjek S1 menyatakan makna teorema } \\
\begin{array}{l}\text { Pythagoras yang diberikan menggunakan } \\
\text { bahasanya sendiri }\end{array}\end{array}$ & $\begin{array}{l}\text { Subjek S1 menyatakan makna teorema } \\
\text { Pythagoras yang diberikan menggunakan } \\
\text { bahasanya sendiri }\end{array}$ \\
\hline
\end{tabular}

Berdasarkan paparan data pemahaman subjek S1 pada Tabel 2, ada konsistensi pemahaman subjek S1 ketika menyatakan makna teorema Pythagoras pada TPKTP I dan TPKTP II, sehingga dapat dikatakan bahwa data pemahaman subjek S1 ketika menyatakan makna teorema Pythagoras menggunakan bahasa sendiri adalah valid.

Hasil tertulis subjek field dependent (S2) ketika menyatakan makna teorema Pythagoras yang diberikan menggunakan bahasanya sendiri dalam TPKTP I untuk nomor 1 dan 3, sebagaimana pada Gambar 3 dan Gambar 4.

1. Teorema Pythagoras adalah sebuah teori untuk menoari salah satu srsi dari segitiga atau sirs yang lain.

Gambar 3. Jawaban Subjek S2.1.1

\begin{tabular}{l}
3 Sebuah segitiga siku-siku dengan srsi miring is $\mathrm{cm}$ \\
Alas $12 \mathrm{~cm}$, dan tinggi g rm yang diarsir didalama terdapat \\
sebuah persegi panjang yang trdak diarsir dan tidak \\
diketahui ukuranya \\
\hline$C^{-2}: B C^{2}-A B^{2}$
\end{tabular}

Gambar 4. Jawaban Subjek S2.1.3

Cuplikan wawancara subjek S2 ketika menyatakan makna teorema Pythagoras yang diberikan menggunakan bahasanya sendiri dalam TPKTP I untuk soal nomor 1 dan 3, sebagai berikut:

$P 2,1,1$ : apa yg anda ketahui mengenai teorema pythagoras?

S2,1,1 : teorema Pythagoras adalah suatu teori yang mencari salah satu sisi dari segitiga atau sisi yang lain

$P 2,1,2$ : ada pendapat lain?

S2,1,2 : emmmm tidak ada (ragu-ragu menjawab)

Cuplikan wawancara subjek S2 ketika menyatakan makna teorema Pythagoras yang diberikan menggunakan bahasanya sendiri dalam TPKTP I untuk nomor 3

P2,1,45 : disini kamu menyimpulkan apa (soal no.3)? 
S2,1,45 : sebuah segitiga siku-siku dengan sisi miring $15 \mathrm{~cm}$, alas $12 \mathrm{~cm}$, dan tinggi $9 \mathrm{~cm}$, yang diarsir didalamnya terdapat sebuah persegi panjang yang tidak diarsis dan tidak diketahui ukurannya

Penjelasan data subjek S2 dalam pengerjaan TPKTP I dan TPKTP II disajikan pada Tabel 3.

Tabel 3. Paparan Data Pemahaman Subjek S2 ketika Menyatakan Makna teorema Pythagoras yang Diberikan Pada TPKTP I dan TPKTP II

\begin{tabular}{|c|c|}
\hline Data TPКTP I & Data TPKTP II \\
\hline $\begin{array}{l}\text { Terungkap bahwa pemahaman subjek S2 } \\
\text { ketika menyatakan makna teorema Pythagoras } \\
\text { yang diberikan menggunakan bahasanya } \\
\text { sendiri dalam TPKTP I }\end{array}$ & $\begin{array}{l}\text { Subjek S2 terungkap bahwa pemahaman } \\
\text { subjek S2 ketika menyatakan makna } \\
\text { teorema Pythagoras yang diberikan } \\
\text { menggunakan bahasanya sendiri dalam } \\
\text { TPKTP II yaitu, subjek S2 menyatakan } \\
\text { makna teorema Pythagoras menggunakan } \\
\text { bahasanya sendiri baik pada soal nomor } 1 \\
\text { seperti terlihat pada } S 2,2,2 \text {. }\end{array}$ \\
\hline
\end{tabular}

Berdasarkan hasil tertulis dan wawancara yang dilakukan. Pada pertanyaan untuk nomor 1 dan 3, yaitu menjelaskan makna teorema Pythagoras yang diberikan, subjek S2 menyatakan makna teorema Pythagoras yang diberikan menggunakan bahasanya sendiri dengan cara membacakan ulang hasil jawaban tertulis. Subjek S2 juga mampu membaca dan menjelaskan dengan baik notasi yang dibuatnya (teorema Pythagoras).

\section{Menggunakan Konsep Teorema Pythagoras Untuk Menyelesaikan Masalah Yang Diberikan}

Hasil tertulis subjek S1 ketika menggunakan konsep teorema Pythagoras untuk menyelesaikan masalah yang diberikan dalam TPKTP I untuk nomor 4, tersaji pada Gambar 5 dan Gambar 6.

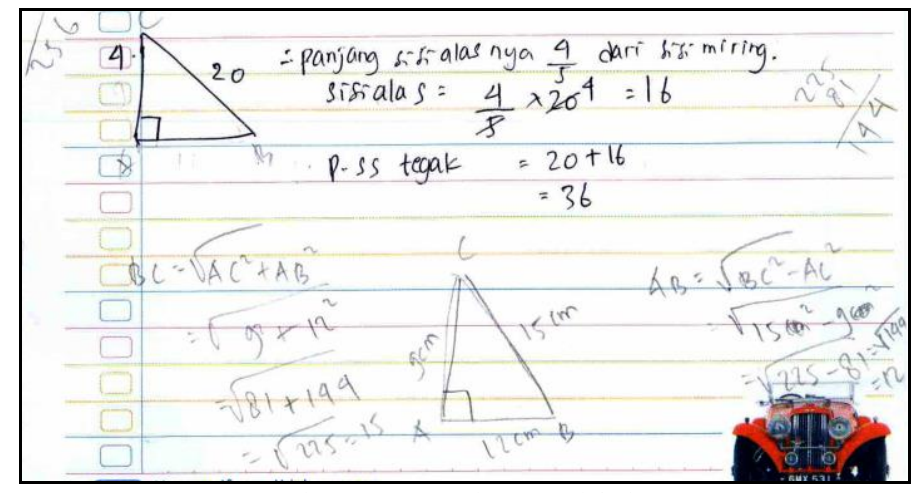

Gambar 5. Jawaban Subjek S1.1.4 


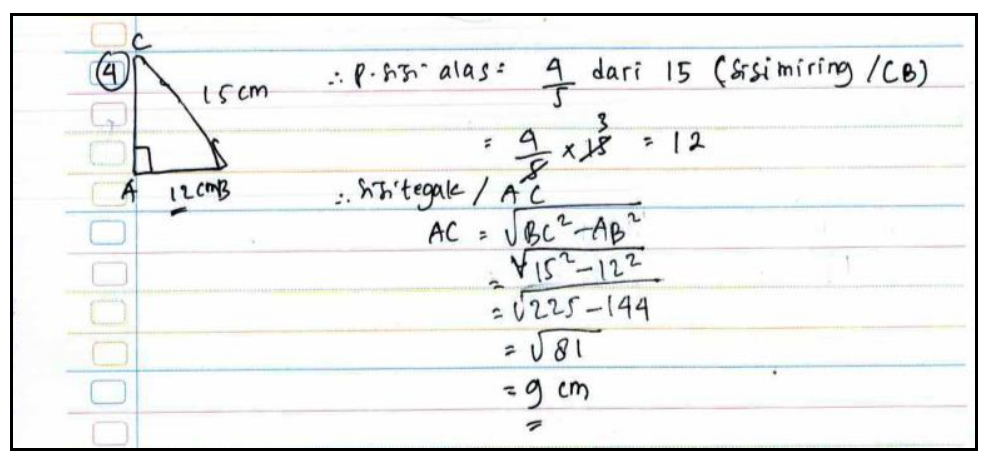

Gambar 6. Jawaban Subjek S1.2.4

Cuplikan wawancara subjek S1 ketika menyatakan makna teorema Pythagoras yang diberikan menggunakan bahasanya sendiri dalam TPKTP I untuk nomor 4.

$P 1,1,42$ : sisi alasnya yang mana?

$S 1,1,42: A B$

$P 1,1,43: A B$ tadi panjangnya berapa?

S1,1,43 : panjang $A B, 4 / 5$ dari sisi miring

P1,1,44 : dilembar jawaban kamu tulis "sisi alas sama dengan 4/5 kali 20”, kenapa 20?

S1,1,44 : karena di soal 4/5 dari sisi miring

Paparan data pemahaman subjek S1 ketika menggunakan konsep teorema Pythagoras untuk menyelesaikan masalah yang diberikan pada TPKTP I dan TPKTP II disajikan pada Tabel 4.

Tabel 4. Paparan Data Pemahaman Subjek S1 ketika Menggunakan Konsep Teorema Pythagoras untuk Menyelesaikan Masalah yang Diberikan pada TPKTP I dan TPKTP II Data S1 pada TPKTP I Data S1 pada TPKTP II Pemahaman subjek pada soal nomor 4

\begin{tabular}{ll} 
Pemahaman subjek pada soal nomor 4 \\
\hline $\begin{array}{l}\text { Subjek S1 menggunakan gambar segitiga untuk } \\
\text { merepresentasikan konsep teorema Pythagoras }\end{array}$ & merepresentasikan konsep teorema Pythagoras \\
yang diketahuinya. Akan tetapi, subjek terlebih & yang diketahuinya. Subjek terlebih dahulu \\
dahulu menentukan nilai yang tidak diketahui dari & menentukan nilai yang tidak diketahui dari sisi \\
sisi alasnya. Kemudian menggunakan teorema & alasnya dengan mengunakan teorema Pythagoras. \\
$\begin{array}{l}\text { Pythagoras untuk menyelesaikan masalah yang } \\
\text { diberikan. }\end{array}$ \\
\hline
\end{tabular}

Subjek S1 mengawali dengan cara mencari nilai alas dengan menghitung sisi miring dikali nilai dari alas. kemudian menyederhanakannya sehingga diketahui besarnya alas dari segitiga tersebut. Setelah itu subjek mengungkapkan bahwa cara yang digunakan barulah langkah awal dan bukanlah cara yang dikehendaki soal. Kemudian menentukan tingginya dengan menggunakan teorema Pythagoras berdasarkan apa yang diketahui seperti terlihat pada $S 1,2,43$. 
Hasil tertulis subjek S2 ketika menggunakan konsep teorema Pythagoras untuk menyelesaikan masalah yang diberikan dalam TPKTP I untuk nomor 4, terlihat pada Gambar 7 dan Gambar 8.

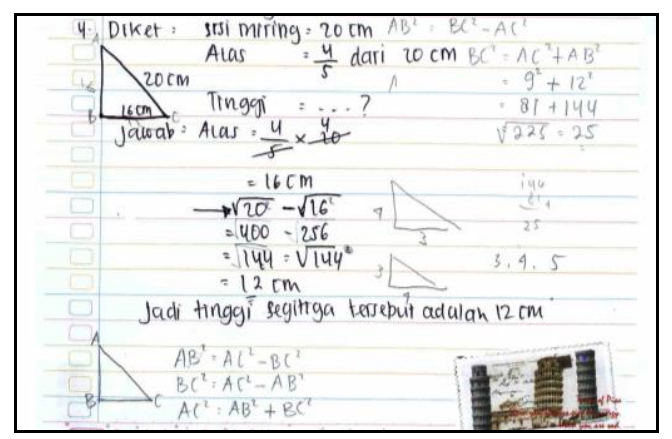

Gambar 7. Jawaban Subjek S.2.1.4

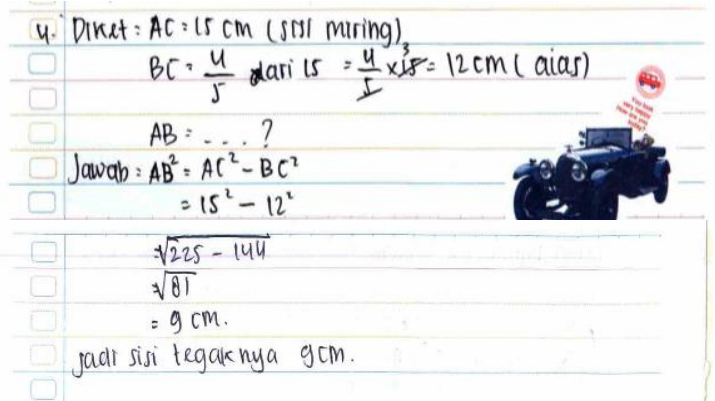

Gambar 8. Jawaban Subjek S.2.2.4

Cuplikan wawancara subjek S2 ketika menggunakan konsep teorema Pythagoras untuk menyelesaikan masalah yang diberikan dalam TPKTP I untuk nomor 4, sebagai berikut:

P2,1,55 : jadi apa yang diketahui?

S2,1,55 : sisi miring $20 \mathrm{~cm}$, sisi alas 4/5 dari sisi miring

$P 2,1,56:$ ditanyakan apanya?

$S 2,1,56:$ tinggi

$P 2,1,57$ : terus?

S2,1,57 : alas sama dengan 4/5 kali 20

P2,1,58 : kenapa dikali 20

S2,1,58 : karena 4/5 dari 20

P2,1,59 : iya, kenapa 20?

S2,1,59 : di soal 4/5 dari sisi miringnya

P2,1,60 : jadi berapa alasnya? 
$S 2,1,60: 16 \mathrm{~cm}$

Paparan data subjek S2 ketika menggunakan konsep teorema Pythagoras untuk menyelesaikan masalah yang diberikan pada TPKTP I dan TPKTP II disajikan pada Tabel 5.

Tabel 5. Paparan Data Pemahaman Subjek S2 ketika Menggunakan Konsep Teorema Pythagoras untuk Menyelesaikan Masalah yang Diberikan pada TPKTP I dan TPKTP II

Data S2 pada TPKTP I Data S2 pada TPKTP II

Pemahaman subjek pada nomor 4

\begin{tabular}{|c|c|}
\hline $\begin{array}{l}\text { nilai dari sisi yang belu } \\
\text { lian menggunakan konse } \\
\text { ras untuk menyelesaik } \\
\text { erikan seperti terlihat pac }\end{array}$ & $\begin{array}{l}\text { untuk menentukan nilai dari sisi yang belum } \\
\text { diketahui. Kemudian menggunakan konsep } \\
\text { teorema Pythagoras untuk menyelesaikan } \\
\text { masalah yang diberikan seperti terlihat pada } \\
S 2,2.42\end{array}$ \\
\hline
\end{tabular}

Berdasarkan hasil tertulis dan wawancara yang dilakukan. Pada pertanyaan nomor 4, yaitu mencari sisi tegaknya. Subjek S2 menggunakan operasi hitung perkalian untuk menentukan besarnya sisi yang belum diketahui. Kemudian menggunakan teorema Pythagoras untuk menentukan sisi tegak sesuai permintaan pada soal.

\section{Menggunakan Syarat Perlu Atau Syarat Cukup Suatu Konsep Teorema Pythagoras}

Hasil tertulis subjek S1 ketika menggunakan syarat perlu atau syarat cukup suatu konsep dalam TPKTP I untuk nomor 2, sebagaimana pada Gambar 7 dan Gambar 8.

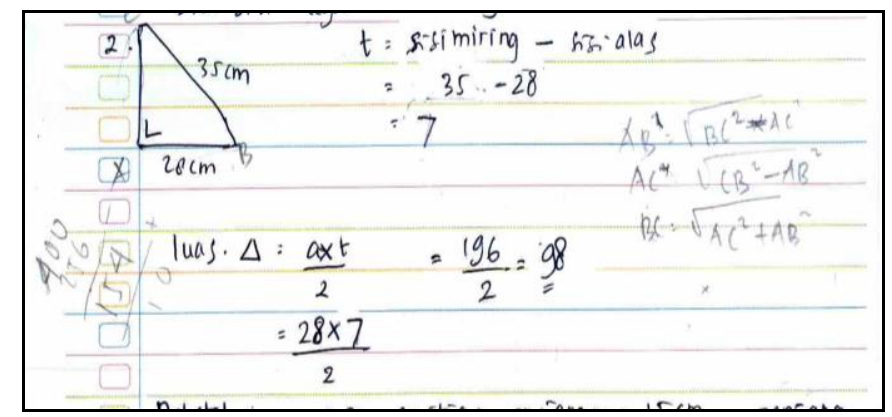

Gambar 7. Jawaban Subjek S1.1.2

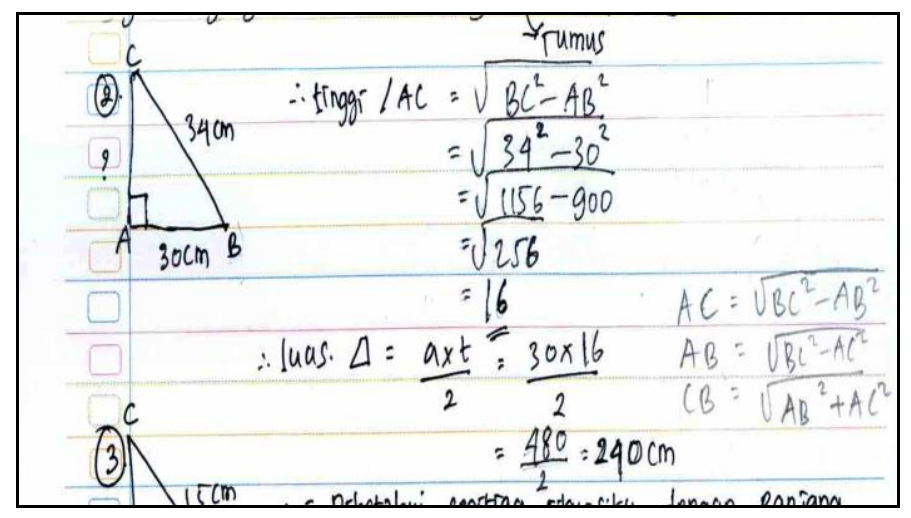

Gambar 8. Jawaban Subjek S1.2.2 
Cuplikan wawancara subjek S1 ketika menggunakan konsep teorema Pythagoras untuk menyelesaikan masalah yang diberikan dalam TPKTP I untuk nomor 2, sebagai berikut:

P1,1,26 : bisa nggak mencari luas segitiga tapi nggak diketahui tingginya?

S1,1,26 : nggak bisa, karena luas segitiga itu alas kali tinggi bagi 2.

P1,1,27 : kalau nggak diketahui sisi miringnya, bisa dicari luasnya nggak?

S1,1,27 : nggak bisa.

P1,1,28 : tadi kamu bilang luas segitiga itu alas kali tinggi bagi dua.

S1,1,28 : eh iya bisa.

Paparan data pemahaman subjek S1 ketika menggunakan syarat perlu atau syarat cukup suatu konsep pada TPKTP I dan TPKTP II disajikan pada Tabel 6.

Tabel 6. Paparan Data Pemahaman Subjek S1 ketika Menggunakan Syarat Perlu atau Syarat Cukup Suatu Konsep pada TPKTP I dan TPKTP II

Data S1 pada TPKTP I Data S1 pada TPKTP II

Pemahaman subjek pada nomor 2

Dari hasil tertulis dan wawancara di atas,

terungkap bahwa subjek mampu menggunakan

Dari hasil tertulis dan wawancara di atas,

syarat perlu atau syarat cukup ketika menentukan

terungkap bahwa subjek S1 menggunakan

menggunakan syarat perlu atau syarat cukup

luas segitiga, yaitu dengan terlebih dahulu suatu konsep untuk menentukan luas segitiga melalui teorema pythagoras dengan terlebih menentukan nilai tingginya. dahulu menentukan nilai tingginya

Berdasarkan hasil tertulis dan wawancara yang dilakukan. Pada pertanyaan untuk nomor 2. Subjek S1 terlebih dahulu menentukan nilai tinggi dari sisi yang belum diketahui, karena menurutnya, luas segitiga tidak dapat dicari jika tingginya tidak diketahui.

Hasil tertulis subjek S2 ketika menggunakan syarat perlu atau syarat cukup suatu konsep teorema Pythagoras dalam TPKTP I untuk nomor 2, sebagaimana pada Gambar 9 dan Gambar 10.

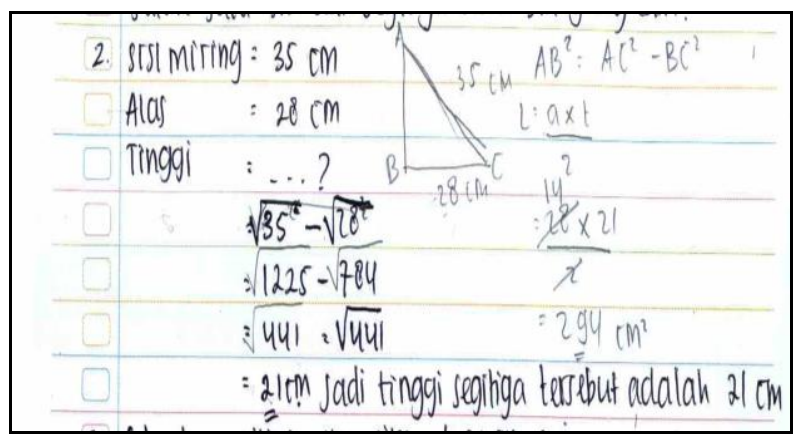

Gambar 9. Jawaban Subjek S2.1.2 


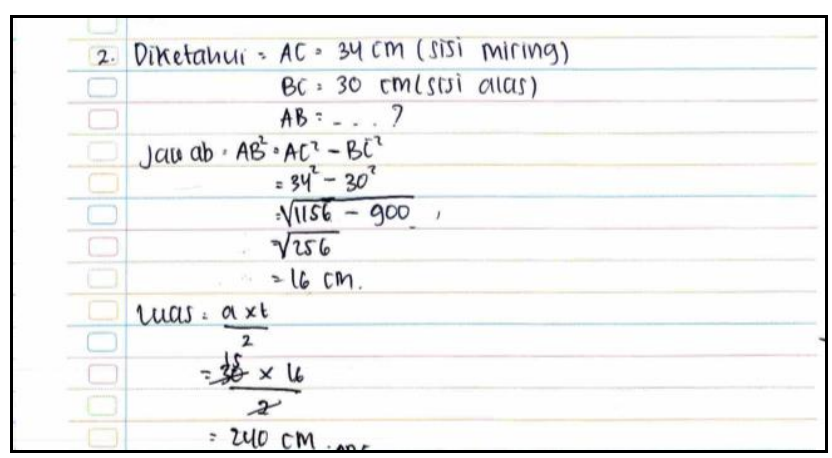

Gambar 10. Jawaban Subjek S2.2.2

Cuplikan wawancara subjek S2 ketika menggunakan konsep teorema Pythagoras untuk menyelesaikan masalah yang diberikan dalam TPKTP I untuk nomor 4, sebagai berikut:

P2,1,34 : luas segitiga rumusnya apa?

S2,1,34 : alas kali tinggi bagi 2

P2,1,35 : kalo panjang dalam cm kalo luas dalam apa?

$S 2,1,35: \mathrm{cm} 2$

P2,1, 36 : jadi berapa luas segitiganya

$S 2,1,36: 294$

P2,1,37 : kalau nggak diketahui tingginya, bisa nggak dicari luanya?

S2,1,37 : nggak bisa

P2,1,38 : kenapa?

S2,1,38 : kan luas segitiga rumusnya alas kali tinggi dibagi dua, jadi harus diketahui tingginya

P2,1,39 : kalau yang tidak diketahui sisi miringnya, bisa dicari luas segitiganya?

S2,1,39 : bisa

Paparan data subjek S2 ketika menggunakan syarat perlu atau syarat cukup suatu konsep untuk menentukan ada atau tidaknya suatu teorema Pythagoras pada TPKTP I dan TPKTP II disajikan pada Tabel 7.

Tabel 7. Paparan Data Pemahaman Subjek S2 ketika Menggunakan Syarat Perlu atau Syarat Cukup Suatu Konsep untuk Menentukan Ada atau Tidaknya Suatu Teorema Pythagoras pada TPKTP I dan TPKTP II

\begin{tabular}{ll}
\hline Data S2 pada TPKTP I & Data S2 pada TPKTP II \\
Pemahaman subjek pada poin a \\
\hline $\begin{array}{c}\text { Subjek S2 menjelaskan bahwa untuk mencari tinggi } \\
\text { menggunakan teorema Pythagoras dan teorema }\end{array}$ dua sisi menjelaskan bahwa jika tidak diketahui \\
Pythagoras tidak dapat digunakan jika hanya ada & digunakan, seperti terlihat pada $S 2,2,24$. \\
satu sisi yang diketahui seperti terlihat pada & \\
wawancara $P 2,1,37$ dan $S 2,1,37$. &
\end{tabular}


Berdasarkan hasil tertulis dan wawancara yang dilakukan. Pada pertanyaan nomor 2. Subjek S2 menjelaskan bahwa untuk mencari tinggi menggunakan teorema Pythagoras dan teorema Pythagoras tidak dapat digunakan jika hanya ada satu sisi yang diketahui disajikan dalam Tabel 8.

Tabel 8. Deskripsi Pemahaman Subjek terhadap Konsep Teorema Pythagoras Berdasarkan Perbedaan Gaya Kognitif Field Independent dan Field Dependent

\begin{tabular}{|c|c|c|}
\hline $\begin{array}{l}\text { Subjek } \\
\text { Indikator } \\
\text { Pemahaman }\end{array}$ & Field Independent & Field Dependent \\
\hline $\begin{array}{l}\text { Menyatakan makna } \\
\text { teorema Pythagoras } \\
\text { yang diberikan } \\
\text { menggunakan } \\
\text { bahasanya sendiri }\end{array}$ & $\begin{array}{l}\text { Menyatakan yang subjek ketahui mengenai } \\
\text { teorema Pythagoras } \\
\text { sendiri. }\end{array}$ & $\begin{array}{l}\text { Menyatakan makna teorema Pythagoras } \\
\text { menggunakan bahasanya sendiri. }\end{array}$ \\
\hline $\begin{array}{l}\text { Menggunakan konsep } \\
\text { teorema Pythagoras } \\
\text { untuk menyelesaikan } \\
\text { masalah yang } \\
\text { diberikan }\end{array}$ & $\begin{array}{l}\text { Menggunakan konsep teorema Pythagoras untuk } \\
\text { menyelesaikan masalah yang diberikan dengan } \\
\text { cara menggunakan gambar segitiga sebagai } \\
\text { representasi untuk mempermudah menafsirkan } \\
\text { letak sisi sisi yang diberikan. Kemudian subjek } \\
\text { mencari nilai yang belum diketahui dengan } \\
\text { mengalikan informasi yang diberikan. Setelah itu } \\
\text { menggunakan teorema Pythagoras untuk } \\
\text { menyelesaikan masalah. }\end{array}$ & $\begin{array}{l}\text { Menggunakan konsep teorema Pythagoras } \\
\text { untuk menyelesaikan masalah yang } \\
\text { diberikan dengan cara menggunakan } \\
\text { operasi hitung perkalian untuk } \\
\text { menentukan salah satu sisi yang belum } \\
\text { diketahui. Kemudian menggunakan } \\
\text { teorema Pythagoras untuk menemukan } \\
\text { jawaban dari soal yang diberikan. }\end{array}$ \\
\hline $\begin{array}{l}\text { Menggunakan syarat } \\
\text { perlu atau syarat cukup } \\
\text { suatu konsep untuk } \\
\text { menentukan ada atau } \\
\text { tidaknya suatu teorema } \\
\text { Pythagoras }\end{array}$ & $\begin{array}{l}\text { Menggunakan syarat perlu atau syarat cukup } \\
\text { suatu konsep untuk menentukan luas segitiga } \\
\text { menggunakan teorema Pythagoras dengan cara } \\
\text { terlebih dahulu mencari sisi (tinggi)nya. }\end{array}$ & $\begin{array}{l}\text { Menggunakan syarat perlu atau syarat } \\
\text { cukup suatu konsep teorema Pythagoras } \\
\text { dengan rus diketahui dua sisi atau tidak } \\
\text { cukup jika hanya diketahui satu sisi saja. }\end{array}$ \\
\hline
\end{tabular}

\section{KESIMPULAN}

\section{Pemahaman Subjek Field Independent}

Berdasarkan hasil penelitian yang telah dilakukan, terungkap bahwa pemahaman subjek field independent terhadap konsep teorema Pythagoras pada indikator pertama yaitu menyatakan makna teorema Pythagoras yang diberikan menggunakan bahasanya sendiri dengan menyebutkan definisi teorema Pythagoras yang ia ketahui.

Sedangkan jika diamati pada indikator kedua, yaitu pada saat menggunakan konsep teorema Pythagoras untuk menyelesaikan masalah yang diberikan. Subjek ini menggunakan gambar segitiga sebagai representasi untuk mempermudah menafsirkan letak sisi sisi yang diberikan. Kemudian subjek mencari nilai yang belum diketahui dengan mengalikan informasi yang diberikan. Setelah itu menggunakan teorema Pythagoras untuk menyelesaikan masalah.

Pada indikator ketiga yaitu pada saat menggunakan syarat perlu atau syarat cukup suatu konsep teorema Pythagoras, terungkap bahwa Subjek field independent menggunakan 
syarat perlu atau syarat cukup suatu konsep untuk menentukan luas segitiga menggunakan teorema Pythagoras dengan cara terlebih dahulu mencari salah satu sisinya.

\section{Pemahaman Subjek Field Dependent}

Berdasarkan hasil penelitian yang telah dilakukan, terungkap bahwa pemahaman subjek field dependent terhadap konsep teorema Pythagoras pada indikator pertama yaitu menyatakan makna teorema Pythagoras yang diberikan menggunakan bahasanya sendiri dengan menyebutkan symbol-simbol yang ia ketahui pada teorema Pythagoras.

Sedangkan jika diamati pada indikator kedua, yaitu pada saat menggunakan konsep teorema Pythagoras untuk menyelesaikan masalah yang diberikan. Subjek ini menggunakan konsep teorema Pythagoras untuk menyelesaikan masalah yang diberikan dengan cara menggunakan operasi hitung perkalian untuk menentukan salah satu sisi yang belum diketahui. Kemudian menggunakan teorema Pythagoras untuk menemukan jawaban dari soal yang diberikan.

Pada indikator ketiga yaitu pada saat menggunakan syarat perlu atau syarat cukup suatu konsep teorema Pythagoras, terungkap bahwa Subjek field independent menggunakan syarat perlu atau syarat cukup suatu konsep teorema Pythagoras dengan menyatakan bahwa harus diketahui dua sisi atau tidak cukup jika hanya diketahui satu sisi saja.

Hal ini sesuai dengan pendapat yang dikemukakan Abidin (2012) yaitu gaya kognitif field indepedent adalah karakteristik individu yang cenderung sulit untuk menemukan bagian sederhana dari konteks aslinya atau mudah terpengaruh oleh manipulasi unsur-unsur pengecoh pada konteks karena memandangnya secara global.

\section{Persamaan dan Perbedaan Pemahaman Subjek Field Independent dan Field Dependent}

Selama proses menyelesaikan masalah kedua subjek telah menunjukkan pemahaman mereka melalui kegiatan yang dilakukannya serta wawancara berbasis TPKTP yang diberikan kepada mereka. Berdasarkan hasil analisis yang telah dipaparkan pada bab sebelumnya, diperoleh bahwa terdapat beberapa persamaan pemahaman yang ditunjukkan subjek dengan gaya kognitif field independent dan field dependent. Dalam hal ini dapat dijelaskan bahwa persamaan keduanya yaitu sama-sama menggunakan cara prosedural seperti menggunakan operasi hitung perkalian untuk menyelesaikan masalah yang diberikan. Persamaan yang lain 
yaitu, keduanya sama-sama menggunakan gambar sebagai rapresentasi dari konsep yang mereka miliki.

Sedangkan perbedaan pemahaman yang ditunjukkan subjek dengan gaya kognitif field independent dan field dependent terdapat dalam beberapa hal. Seperti pada indikator pertama yaitu menyatakan makna teorema Pythagoras yang diberikan menggunakan bahasanya sendiri. Subjek field independent menyatakan makna teorema Pythagoras yang diberikan dengan menyampaikan definisi yang ia ketahui sedangkan subjek field dependent menyatakan makna teorema Pythagoras yang diberikan hanya terpaku pada notasi notasi pada teorema Pythagoras sehingga subjek tidak dapat mengkaitkan antara fungsi notasi yang diketahui dengan teorema Pythagoras yang ada pada soal.

\section{REFERENSI}

Abidin, Z. (2012). Intuisi Siswa dalam Pemecahan Masalah Matematika Divergen Berdasarkan Gaya Kognitif Field Independent dan Field Dependent. Disertasi. Universitas Negeri Surabaya.

Cools, E. (2009). A reflection on the future of the cognitive style field: A proposed research agenda. Reflecting Education, 5(2), 19-34.

Darminto. (2009). Upaya Peningkatan Pemahaman Konsep Aljabar dan Sikap Mahasiswa Calon Guru Matematika terhadap Pembelajaran Berbasis Komputer. Dipresentasikan dalam Seminar Nasional Aljabar, Pengajaran dan Terapannya dengan tema Kontribusi Aljabar dalam upaya meningkatkan kualitas penelitian dan pembelajaran matematika untuk mencapai world class university. Pendidikan Matematika, FMIPA UNY, Yogyakarta.

Dimyati \& Mujiono. (2009). Belajar dan Pembelajaran. Jakarta: PT. Rineka Cipta.

Ghazali, N. H. C. \& Zakaria, E. (2011). Students' Procedural and Conceptual Understanding of Mathematics. Australian Journal of Basic and Applied Sciences, 5(7), 684-691.

Hamalik, O. (2009). Proses Belajar Mengajar. Bandung: Bumi Aksara. 
191 KALAMATIKA, Volume 03, No. 02, November 2018, hlm. 175-192

Ikrima, R. D. (2015). Meningkatkan Pemahaman Siswa Tentang Teorema Pythagoras Dalam Penyelesaian Bangun Datar. Skripsi Tidak Dipublikasi. Tulungangung: IAIN Tulungagung.

Liu, Y., \& Ginther, D. (1999). Cognitive styles and distance education. Online journal of distance learning administration, 2(3), 1-19.

Minggi, I. (2010). Profil Intuisi Mahasiswa dalam Memahami Konsep Limit Fungsi Berdasarkan Perbedaan Gender. Disertasi Tidak Dipublikasi. Surabaya: Universitas Negeri Surabaya

NCTM. (1989). Curriculum and Evaluation Standards for School Mathematics. Reston, VA: NCTM

Riding, R. J. (1997). Cognitive style and learning strategies: some implicatations for training design. International Journal of Training and Development, 1(3), 199-208.

Sugiyono. (2012). Metode Penelitian Kuantitatif, Kualitatif dan R\&D. Bandung: Alfabeta

Uno, H. B. (2006). Orientasi Baru dalam Psikologi Pembelajaran. Jakarta: Bumi Aksara. 
Nurafni, Miatun, \& Khusna 192 